\title{
Epiphany
}

Epiphany: Vol. 4, No. 1, 2011

ISSN 1840-3719

\section{Religious Conversion, Models and Paradigms}

Tuba Boz

\begin{abstract}
This papers examines the experiences of converts to Islam among Australian women in the milieu of polemic views and debates such as 'Islam versus the west', which is most visible in the image of the 'eastern' 'oppressed' Muslim woman. Employing the experiences of Australian Muslim women converts in Melbourne, issues concerning identity politics, and the individuals and social dimensions of conversion are investigated. While there is an array of literature about Muslim women from various disciplines including anthropology, sociology, politics, cultural studies and gender studies, among others, this paper takes an interdisciplinary approach to examine debates that have based their discussion on the image of the Muslim woman. Marco debates concerning issues such as multiculturalism, integration, Islam and the West debates including the 'clash of civilizations' have been largely centred on the image of the Muslim women. The debate concerning the inherent conflict between Islam and West intensified after $11^{\text {th }}$ of September 2001 with the terrorist attacks in the United States and the invasion of Afghanistan in 2001 and Iraq in 2002. It is during this critical period I interviewed Muslim converts in order to gain first-hand insight into their experiences as Muslims. This paper employs primary data collected during this historical period to examine issues regarding broader issues of identity politics, religious conversion as well as the everyday life experiences of female converts to Islam.
\end{abstract}

Keywords: Muslim women, religious conversion, Islam, hijab, Australia and identity politics

\footnotetext{
* Corresponding author: Tuba Boz; Faculty of Arts and Social Sciences, International University of Sarajevo, Sarajevo, Bosnia and Herzegovina; e-mail: tboz@ius.edu.ba ; boz.tuba@gmail.com
} 


\section{Introduction}

Female conversion to Islam and similar debates on gender issues, whether statistically, ideologically, or symbolically, has been pivotal in the construction of otherness between "Islam" and the "West" (Karen van Nieuwkerk, 2006, p. 1). Therefore, this paper examines the experiences of converts to Islam among Australian women in the milieu of polemic views and debates such as 'Islam versus the west', which is most visible in the image of the 'eastern' 'oppressed' Muslim woman. Employing the experiences of Australian women converts to Islam in Melbourne, issues concerning identity politics, and the individuals and social dimensions of conversion are investigated. While there is an array of literature about Muslim women from various disciplines including anthropology, sociology, politics, political science, cultural studies and gender studies, among others, this paper takes an interdisciplinary approach to examine debates that have based their discussion on the image of the Muslim woman. Marco debates concerning issues such as multiculturalism, integration, Islam and the West debates including 'clash of civilizations' have been largely centred on the image the 'subjugated' and 'foreign' Muslim woman.

This paper uses a micro approach to question the macro issues of integration, identity politics and the 'clash of civilisations' by focusing on the experiences of female converts to Islam in Melbourne. However, the clash between religion, nationality and ethnicity seems absurd when one considers the Anglo-Muslim woman. Is it a matter of lost identity? Where does one's "Australianess", "Englishness", Americaness or "Frenchness" go when one converts to Islam? Is it not possible to be French and Muslim or Australian and Muslim? Does one lose their French or English speaking capabilities upon conversion?

The debate concerning the inherent conflict between Islam and the West intensified on $11^{\text {th }}$ of September 2001 with the terrorist attacks in the United States and the invasion of Afghanistan in 2001 and Iraq in 2002. At this time, Samuel Huntington's thesis on the Clash of Civilisations (1993), which made a significant contribution to academic, and policy debates gained much attention and influenced the discussions 
regarding Islam and the 'West'. It is during this critical period I interviewed Muslim converts in order to gain first-hand insight into their experiences as Muslims. This paper employs primary data collected during this historical period to examine issues regarding broader issues of identity politics, the motivation for conversion as well as the everyday life experiences of female converts to Islam.

A qualitative approach was taken to gather empirical data. There were forty participants or which 21 were female. For the purpose of this paper, only the experiences of female participants will be discussed. The participants come from different life styles and experiences and as the following discussion will show, these converts share surprisingly similar experiences during the conversion process. Aliya, formerly Christian converted in 2002. She works as an insurance consultant. Aisha, Tracey and Jan converted to Islam from Christianity and their occupations vary from working as a film editor, to studying Media studies or working as an administrator. The stories of Aliya and Jan will be used to a large extent as their experiences are compelling and shed light on the general experiences of Muslim women converts in Melbourne who participated in this study.

Before delving into the theoretical definitions of religious conversion, and what constitutes religious conversion, it is essential to clarify terminology. The vast proportion of the participants in this study prefer the term "revert" to "convert" due to an Islamic notion of fitrah, a natural disposition in every human being that is inclined towards the belief in One God. As Mohamed (1998:3) states, "The term fitrah literally means, "...an inborn natural disposition which cannot change, and which exists at birth in all human beings." As such, the individual is socialised into a different way of life. However for the purpose of this paper the term converts will be used.

\section{Models and Patterns of Religious Conversion}

Abdullah Saeed (2003) writes that more than 36 percent of Australian Muslims were born and raised in Australia and many are 'converts to Islam from European and other backgrounds' (page vi). Saeed (2003) sheds light on the multiculturalism debate Australia. He 
explains that 'Ignoring the fact that Australia is a multicultural and multireligious society and that the Muslim community is extremely diverse, some influential commentators and even politicians suggested that Australia should rethink its policy concerning Muslim migration (p.187). He argues that, "this is based on the notion that Muslims are a single formidable mass whose ideal and values do not fit in western society and conflict with basic Australian 'Judeo-Christian' values. (p. 187). It is this very notion of an inherent conflict between Islam and western society, and the stereotype that being Muslim is linked with particular nationalities and ethnicity that converts to Islam help to dispel. Gary Bouma (2006) unpacks the notion of multiple identities as well as religiosity and spirituality. This is particularly useful when one considers converts to Islam. For example, pertaining to religious identity, Bouma reflects upon his own identity. He states:

From a demographic perspective, a person's religious identity is taken to be, like other kinds of identity, what they say they are when they are asked who they are. Who are you? I am male - gender identity, Dutch American and English - ethnic identity, Australian - national identity, married - marital status identity, Anglican - religious identity, a green - political identity, a Melbourne supporter - sporting identity... (p. 50).

According to James A. Beckford (2003), "one of the reasons why the topic of religion is a challenge for simplistic version of globalisation is that, by definition religion is self-reflexive. Religions are not simply the effects of external forces; they are also agent, observers and critics of their own development' (p. 105). In light of this statement, one can also examine religious conversion in the context of self-reflexivity. Before delving further into the experiences of female converts to Islam in Melbourne, I will provide an overview of the religious conversion process in general. In order to better understand the conversion process, a seven-stage model developed by Lewis Rambo and Charles E. Farhadian is used to display the phases of the process that takes place over time. These seven stages are: (1) Context, consisting of the overall environment in which change takes place, factors when facilitating or constraining 
change; (2) Crisis, a stage in which there is a rupture in the taken for granted world which leads to the; (3) Quest stage in which the individual actively seeks meaning and a new way of confronting their problem; (4) Encounter is contact between the questioner and the advocate of a new alternative; (5) Interaction is the intensification of the conversion process whereby the potential convert and advocate confer changes in perceptions and actions; (6) Commitment is the stage in which the questioner makes the decision to change their life and adopt a new belief system and (7) Consequences involve collective effects of various experiences, beliefs and actions that can either facilitate or hinder their conversion.

Rambo and Farhadian state that it should be taken into account that the stage model should not be seen as unilinear or universal. The stage model is intended to be heuristic and the effectiveness of the model lies in its ability to systematically organise the complex phenomena of religious conversion, as well as some technical issues arising in conversion scholarship. The stages should not be seen as necessarily occurring in the sequence as presented in the model (Rambo \& Farhadian, 1999: 24). In contrast, Lofland (1966) emphasizes the significance of the order of the stages one must go through for conversion to occur. He states:

For conversion it is necessary that a person, 1. experience enduring, acutely felt tensions; 2. within a religious, problem solving perspective; 3 . which lead to defining himself as a religious seeker; 4 . encountering the cult at a turning point in his life; 5 . wherein an effective bond to adherents is formed (or pre-exists); 6. where extra-cult attachments are low or neutralized 7. and where, "to become a "deployable agent" and, exposure to intensive interaction is accomplished (Lofland, 1933:7-8).

While there is a distinction between conversion to a cult and conversion to a mainstream religion such as Islam, this theory which draws from Lofland's own research on converts to the cult called-Divine Precepts, may be applied to my research, the responses ascertained from my study diverge from his theory as some of converts did not necessarily experience acutely felt tensions within their religion, nor did they 
consider themselves religious seekers. Rather, they "bumped" into Islam, or were researching it not with the intention of converting, but to gain information as they had some sort of interaction with a Muslim, or just for curiosity's sake. This is not to say Lofland's theory cannot be applied to the experience of other converts, as some of the converts in this study have given a detailed explanation of their spiritual quest, but it is not "necessary" that one go through these "stages" for conversion to occur. This is where the line is drawn between the psychological and sociocultural theories pertaining to religious conversion.

A significant factor appearing in both models that influences the conversion process is social interaction with adherents of that faith. Conversion cannot be separated from relationships, processes and ideologies, as it is these, which provide the prevailing conditions for religious change. Moreover, it is important to note that there are Islamic tenets which allow for marriage between Muslim men and Christian and Jewish women, however there is a condition for non-Muslim men to declare their faith in Islam for a marriage to be valid according to Islamic beliefs. Dimensions of the conversion process are manifold, interactive and cumulative, and "in order to gain a rich understanding of conversion, the domains of anthropology, sociology, psychology and religious studies need to be taken into account" (Rambo \& Farhadian, 1999:24). Hefner (1993) in his Conversion to Christianity: Historical and Anthropological Perspectives of a Great Transformation states, "contrary to some psychological accounts of conversion (James 1982, Nock, 1933), however, we must not assume that such a deeply systematic rationalization is necessary or intrinsic to religious conversion. Making such an assumption is to project an interiorist bias onto a phenomenon that comes in a wide array of psycho-cultural forms" (p. 17). Nock (1933) is a prominent theorist of religious conversion in the domain of psychology. He defines conversion as "...the reorientation of the soul of an individual, his deliberate turning from indifference or from an earlier piety to another, a turning which implies a consciousness that a great change is involved, that the old is wrong and the new is right" (p. 7). Hefner, in his book, consisting of several essays of the conversion phenomena demonstrates the variability of conversion. He argues that 
interpretation of conversion needs to begin with the acknowledgement of its experiential variations, and then to go onto the explorations of its origins in various social and intellectual conditions. He (1933) states that: accounts of conversion that emphasize its putative psychological reality such as the classic essays by Nock (1933) and James (1982) or a surprising number of studies in contemporary American sociology (Snow and Machalek, 1984) - remain incomplete if they neglect the broader context that informs the self-and situationalevaluation of the converted. Politics and social ethics are intrinsic to the psycho-cultural reality of conversion, informing on agent's commitment to an identity and moral authority that commitment implies. From the perspective rather than oppose psycho-cultural models of conversion, against socio-political ones, we should insist on and explore this interpretation. (p. 28).

Hefner puts forth that the challenge in the controversy of religious conversion, is to strike a balance between two extremes of intellectualist voluntarism and structural determinism. Conversion encounters are always double sided, and the social and intellectual aspects both affect the outcome. He argues that both the intrinsic and extrinsic variables in conversion should be examined, although the interaction of the two may vary in different contexts.

Hefner (1933) avers that the most significant feature of religious conversion is not a deep systematic re-organisation of personal meanings, but rather an alteration in self-identification through nominal acceptance of religious beliefs or actions perceived to be more suitable or true, "...conversion implies the acceptance of a new locus of self-definition, a new, though not necessarily exclusive, reference point for one's identity" (p. 17). He draws on one of the essays in his book written by David Jordon whereby he explains conversion as a matter of belief and social structure, of faith and affiliation. William Merrill and Charles Keyes, also having written essays for this book, claim that religious conversion does not necessarily reformulate the individual's understanding of the ultimate conditions of existence, but it always entails a new kind of commitment 
to a new moral authority and a reconceptualised social identity. Furthermore, Hefner (1993) confers that

...conversion is related to a process of identity development often referred to as "reference group" formation. Bridging social psychology and the sociology of knowledge, reference group theory emphasizes that self-identification is implicated in all choice, in all matter of self-interest, and in the myriad of conflicts and solidarities of human life (p. 25).

The responses of the converts in this study demonstrate the personal and social effects of their conversion, with converts describing their selfidentification transformation from having found a purpose in life in worshipping Allah to belonging to the trans-national Islamic community -ummah.

The reasons for conversion to Islam vary among the converts. Theoretical and theological assumptions can be drawn from the responses. William James observed conversion as a "personal experience" whereas John Lofland and Rodney Stark see it as a social process. This is not due to the data they examine being divergent in themselves, but rather they had different theoretical assumptions and deployed methodological procedures which lead them to examine conversion in one way or another (Gallegher, 1990:136). Gallegher himself opts to see, “... religion as primarily public and social rather than private and individual” (Gallegher, 1990:139).

\section{Ethnographic Analysis of Religious Conversion}

Social and personal elements play as essential role in converting to Islam. Aliya is Anglo-Australian. She had a preconception of Islam that was quite negative and had a view of Muslims as patriarchal, oppressive toward women and terrorists. Aliya blames the media to a large degree for depicting Islam with such bias and negativity, she asserted during the interview: "Oh, the media has so much to answer for, I had them pegged as people who are violent, extreme, limited and women were oppressed." 
An interesting aspect of Aliya's conversion to Islam was that it was triggered by an article in a newspaper portraying Islam as a religion of violence, intolerance and injustice. An extensive quote from the interview is included to convey her experience, she elucidates:

I think what sparked my journey to Islam was, one day, it was about two and a half years ago, there was a clipping in the newspaper about a girl in Mozambique who was going to be flogged because she was pregnant. The police accused her of premarital sex. She claimed she was raped, and because she didn't have any witnesses, which of course to rape, you're obviously not going to do it in the middle of the city, and the man who said that he had sex with her had a witness, got a guy to say that she consented, and she had nobody. I was really upset about this. For some reason this particular story disgusted me.

So, I couldn't believe it, so anyway, I went and contacted AMNESTY international and they kept me in contact about this particular girl, but I still wasn't happy because with AMNESTY international, you still don't know exactly what's going on. So in an attempt to get some kind of basic explanation, I went to the Preston Mosque, I walked in there, he was very nice, I explained the situation, how could this possibly happen and I don't know why I expected him to think he could fix something happening in Mozambique, but I did. I thought he could contact somebody and basically do something. Anyway, he sat there and listened to my worries and concerns, then he picked up the Quran and started reading some scripture from it. Then he explained the Shariah in its totality... He gave me a copy of the Quran and I just knew that it was a very special book, and was very protective of it, but he never told me anything of that, never told me how to treat it, he just gave it to me and said feel free to read it if you want, which I didn't but at the same time I knew the book was precious. I came home and basically felt extremely spiritual, I saw, how he treated me, we were talking about women in Islam, and I thought to myself, there are a lot more answers here than I had been previously given, and um so anyway, I could say that was the real and solid turning point. There is a culture within the religion, which I really really loved, so I think that was an 
inspiring aspect. There's real respect between men and women, on a more personal level.

Aliya had come across the Islamic way of life as she lived in an area highly populated with Muslims. Being in contact with Muslims is a significant factor contributing to the context of her conversion. Aliya's strong sense for social justice, which is reflected in her response to the newspaper article, she had come across prompted visit to the mosque to enquire about the teachings of Islam. As such, her encounter and interaction with Muslims were essential in her decision to convert, hence commit to Islam. The encounter and interaction stages with Muslims can be understood in context of $d a$ 'wah, (advocacy) inviting others to Islam.

While the motivations for conversion varied, seven females stated that their interest in Islam emerged from their interest in their partner. Aisha confers, "I was seeing a Muslim man who told me about the religion and recommended that I study it". Similarly, Jaylan tells of her motivation for conversion, "meeting my husband, he had different beliefs and I wanted to understand them." Tracey's conversion was influenced by her interest in her partner; she stated that "meeting my husband" was an underlying reason for interested and subsequent conversion to Islam. Jan stated, "I was searching to fill a gap in my life, to rediscover religion when I met a Muslim man who said the right words at the right timeAlhamdulilah." Jan further elaborated that "although her interest in Islam was caused by her meeting her husband, in no way was he the cause for her conversion." I asked Jan what in fact was the cause of her conversion. She explained:

I find this a really hard question to answer because, there was a trigger, which is my current husband, because he introduced me to Islam, as I often say and I know lots of other reverts say this, he is not the reason, but he is certainly the trigger, but the reason is I really was looking for something. I was really searching to discover religion.

The issue of whether you convert for your partner, or because of your partner, one of the things that was really important to me is that to pursue Islam separately from my husband. I really needed to keep it separate because in the 
beginning, I really, I didn't want to confuse the two, because my feelings for him were growing, and my interest for Islam was growing, and there was this danger in confusing the two and I had to be really clear that my motivations were pure. The only way I could be sure in my heart is to separate the two, so I mean, he even felt that I turned elsewhere for information too much.

The conversion process should not be seen as taking any sequential order. The converts were not necessarily on a spiritual quest when they converted to Islam. Rather an interaction with Muslims has been the main cause of interest in Islam, and by following up this interest with research, they found Islam appealing and convincing.

\section{Muslim hijab: A Symbol of Freedom, Oppression or Debate}

The hijab has been framed and employed as a polemic symbol indicating a barrier of Muslim women's' integration into Western societies and in more extreme cases as the very symbol of the 'clash of civilisations'. The framing of Muslim women as 'oppressed' can be seen in both scholarly literature as well as the news media and entertainment industries. Books such as Princess (1993), films such as Not without my daughter (1991) and feminist writers who have a Eurocentric understanding of what women's rights means have subjected Muslim women to their own normative understanding of what is or is not a woman right, what women should or should not wear and how women should lead their lives.

The exploitation of the hijab wearing Muslim woman is particularly evident in the political arena in much of the western nations including France and Germany where the far-right view the hijab as an insult to the secular political system. The hijab also continues to be unresolved issue in Turkey reflecting more of Turkey's identity crisis rather than a merely perceived offence to its secular political system. While now, with the fall of Ben Ali's authoritarian regime in Tunisia, women can now practice their human right to freedom religion and expression and are able to wear the hijab or niqab if they choose so. Although, once again political debate is being centred on the hijab and 
niqab in Tunisia with the secular and religious sections of the society debating an issue, which should simply be left up to the individual woman to decide. Just as it is an insult to force women to wear the hijab, it is equally an insult to ban it.

An illustrative example of the politicisation of hijab can be seen in a recent article programme on Al-Jazeera World (7 December 2011) in a story titled, Muslims of France: What challenges have generations of Muslim immigrants in France been facing to retain their cultural identity? The image of the woman wearing the face cover, niqab, is placed alongside an image of the French revolution and a Muslim in prayer. While the issue here is about immigration, integration and citizenship in France, the idea that there is a clash between Islam and the West, between Muslims and West is connected to a misconception that only migrants are Muslims. The misnomer that "all Muslims are Arab and all Arabs are Muslim" continues to exist in the 21 st century. As such, the debate is centred on migration and this subsequently influences the broader identity politics debate. However, when one considers Muslim converts, the dichotomous approach becomes weaker. While I recognise indeed there are issues concerning migration and integration, the questions related to being Muslim should not conflated with immigration and citizenship debates.

Further, Willy Jansen (2004) makes an important observation concerning the experience of female converts to Islam demarcating the 'gendered' experience of conversion to Islam.

Gender not only intersects with the freedom and reasons to convert, but also with the effects of conversion. It affects the ways in which the person expresses and incorporates his or her new beliefs, and how others react to that. One example is the adoption of the symbols used to express the new faith. For instance, a beard or male circumcision evokes far less reaction than taking on the veil. Western society has made the hijab and the subordinated position of women into symbols of the "Otherness" of Islam, which raises the question of how female converts deal with this and give meaning to it. (p.99) 
The hijab is an important aspect of the Muslim woman's identity, as it is a visible display of their faith. Further, the hijab can also be seen "... as an affirmation of their love for God and pride in their religion. Some also see it as a feminist statement that says: "judge me on the basis of my personality and intellect. Not on my beauty or body shape" (Shaw cited in Bouma, p. 57). In order to gain a deeper understanding of how conversion to Islam may have affected the identity of Muslim converts, I asked several questions about lifestyle choices and whether hijab, was adopted. I asked this because it is imperative in finding out how they identify themselves personally and publicly. Furthermore, in order to see how the wider community responded to their identity as a Muslim, I asked whether they had encountered any type of discrimination.

The female converts reported some changes to aspects of their identity. This is illustrated in the accounts below:

From the time I put on the hijab, I became conscious that I was a representative of the Muslim community. In every way, shape and form I consider myself a Muslim. It's just who I am now (Jaylan).

I have become part of a subculture in my own society. I sometimes feel I do not belong, I feel alienated from mainstream culture (Nadia).

People don't seem to perceive me as an ordinary Australian anymore; they see me as a non-western person (Aysha).

I have grown stronger in my belief in Allah and in the hereafter. I have become more God conscious in all that I do. I know clearly that I am a Muslim and that does not contradict with being an Australian Muslim because Islam is not inherited to a race (May).

Nadia and Aysha appear to place significance on their identity being affected from the perspective of the wider community, hence from the social realm. They feel alienated after having converted to Islam. May's response can be analysed from two aspects of her identity change; becoming more God conscious demonstrates the change on a deeper 
consciousness level, stating the trans-national aspect of Islam illustrates the sense of cosmic identity that has emerged as a result of converting to Islam. Such identity transformations occur on both a personal and social level. Bourque (1998:11) states, "Part of the creation of the Muslim social identity involves learning how to take up their new role as a Muslim when interacting with members of British society." Interaction with the wider community may be difficult for the converts if they are viewed as alien and feel isolated in their homeland.

\section{Religious Conversion and Public Perceptions}

The overall experiences of the Muslim women converts in Melbourne has not been and smooth and easy. The reactions of family and friends were generally one of dismay and fear. Noor explained her family's reaction toward her decision to become Muslim. Her "family was shocked but friends gradually accepted". On the contrary, Maryam stated, "My friends thought I was mad, with preconceptions of Islam, my family have been very supportive." Nadia reported that there "shock, sadness, concern for my well being". May explained, "My family was extremely upset, they didn't speak to me for nearly three years, my friends moved away from me except for a few." Khadija declared, "my family to this day do not support the fact that we are as they call "extreme", although they have calmed down a lot". Aisha revealed, "My dad accepted it right away, and wrote to me while I was still in Pakistan to tell me that he still loved me. My siblings thought it was "cool". My friends thought it was unusual but interesting. My mum didn't like it at all and gave me grief about it for a year or so." Hence, even if the family initially reacted negatively to the conversion, the majority eventually accepted it. Carol Anway (1996:52) in her study of female converts in America likewise found that, "Although families may have reacted with shock and grief at first, they were willing to work through their relationship..."

Sarah, an Italian convert from the Catholic faith, experienced much difficulty with the reaction of her family towards her conversion to Islam. She sheds light on the reaction of her parents: 
They disapproved, they disowned me, but Alhamdulilah, after two, three years my mum came round, and my father came round after seven years. But he is still negative. He mutters, we try not to discuss religion; you can't talk to him because he is so against it. He doesn't want to know. He calls us, "you people, you people this, you people that". He doesn't refer to us as Muslims.

My father, he sees my son in the abayah, [Islamic attire] he says to him, and I'm glad my son doesn't understand, because he is a six year old boy, he says to him, take it off, you look like a priest, and I'm thinking to myself, you should be happy if he is looking like a priest, you know, subhan'Allah, I said, don't you get it, don't you get it? I said, you Christians don't even know it, you're really Muslims, you don't even know it, you really don't know it, wake up, wake up, you're saying my son looks like a Christian, wake up.

Jan reported a variety of responses she received from family and friends to her conversion,

I've had every possible reaction. I've had you know people who have been interested and supportive and have been quite positive about it seeing me happy, and I have people who are completely not accepting of it, and think that I've turned into something with three heads, completely contemptuous of me, and I've had everything in between but the reaction that most bothered me and still does are the people who just don't know what to do with it, they completely shy away from it, they don't ask a single question. I mean it's in their face that I've changed, but they don't ask, they don't want to know, or they feel threatened by it, but I'd rather have the people who are angry about it, challenge me, at least get me talking and at least give me an opportunity to talk about it rather than those who just pretend it's not happening.

The reactions that have been narrated display the initial fear the family and friends of the converts had with the conversion. The eventual acceptance demonstrates that once they had a better understanding of the 
belief and new life style of the convert, they learnt to accept it, and in some instances became rather supportive of it. Nonetheless, the contemptuous reactions of others have caused grief for some of the converts; whilst some converts have chosen to disregard it stating that they were not true friends to begin with. Establishing revert support groups is one way Muslim converts overcome some of the challenges they are faced with when family and friends respond negatively to their decision to become Muslim. Such support groups are also vital in providing Islamic education so that one may discern what it in fact Islamic or an ethnic cultural practice. Hanifa Deen (1995) writes:

Shedding cultural practices can become a full-time occupation for well-educated female converts to Islam women on a voyage of self-discovery who have converted purely for religious and philosophical reasons not because their husbands are Muslims or their partners converted, or because of some obvious emotional need. Several such women have organised support groups for those converts experiencing a form of cultural shock and need advice (p.186).

The 'sisterhood' that emerges among the female converts to Islam is important in dealing with such a change. The groups assist the converts to deal with the responses of their family and friends as well as their encounters with the Muslim communities. For example the 'Revert Support Group' meetings organized with the Islamic Council of Victoria provides such an opportunity for Muslim converts both, female and male. Significantly the 'new' Muslim is able to understand what in fact is Islamic and what an ethnic or cultural practice is.

\section{Conclusion}

The experiences of Australian women converting to Islam are important to consider in the broader context of integration, multicultural, identity politics and Islam versus the west debates. The decision of women to become Muslim and to wear the hijab highlights the complexity in which macro debates concerning the 'clash' or conflict between Islam and the west as such dichotomous approaches are too 
simplistic and do not adequately address the issue of agency and selfreflexivity women employ in deciding how to lead their lives.

Religious conversion is as much a social process as much as it is a profound, personal and individual decision and experience. The decision to convert to Islam varies from a deep-rooted belief in social justice to a desire to better understand the religion of one's partner. Significantly, one does not have to be on spiritual quest to make a decision to change religion, interaction with other Muslims, a newspaper article or a Muslim partner is sufficient to spark an interest and subsequently an investigation of Islam. Upon conversion to Islam, the social process of becoming a member of the ummah is at once a source comfort but it also presents a challenge for the new Muslims who have to be discerning between ethnic and cultural practice and Islam. As such, 'Revert Support Groups' provide an opportunity for new Muslims to meet others who have shared experiences, providing a social environment as well as an educational environment.

Significantly, the challenges encountered by some women who convert to the religion of Islam are rather related to socio-cultural aspects of life. However, overtime many families became more accepting and welcoming of their family member's decision to convert. Such changes will hopefully eventually help dispel the misconceptions of Muslims as either 'terrorists' or the subjugated 'oppressed women' or 'non-Western'.

\section{References:}

Al-Jazeera World (7 December 2011). Muslims of France. (Programme). Anway, C. (1996). Daughters of another path: Experiences of American women choosing Islam. United States: Yawna Publications.

Beckford, J. A. (2003). Social theory and religion. United Kingdom: Cambridge University Press.

Bouma, G. (2006). Australian soul: Religion and spirituality in the twenty-first century. Melbourne, Australia: Cambridge University Press.

Deen, H. (1995). Caravanserai: Journey among Australian Muslims. NSW, Australia: Allen \& Unwin. 
Gallagher, V. Eugene, (1990), Expectation and experience: Explaining religious conversion. Atlanta: Scholars Press.

Gilbert, B. (1991). Not without my daughter. United States: Pathe Entertainment

Hefner, W. Robert. (1993). Conversion to Christianity: Historical and anthropological perspectives on a great transformation. United Kingdom: University of California Press.

Huntington. S.P. (Summer 1993). 'The clash of civilizations?' Foreign Affairs. Vol.72(3) pp. 22(28)

Lofland, J. (1966). Doomsday cult: A study of conversion, proselytization, and maintenance of faith. New Jersey: Prentice Hall.

Jansen, W. 2004. "Conversion, marriage and gender: Jordanians and the Christian Mission." SMT Swedish Missiological Themes/Svenksk Missions Tidskrift 92 (1): 99-122.

Nock, A.D. (1933) Conversion: The old and the new in religion from Alexander the Great to Augustine of Hippo. Oxford: Clarendon Press.

Personal interviews, in 2002 held in Melbourne, Australia.

Rambo, L. \& Farhadian, C.E. (1993) Understanding religious conversion. New Haven \& London: Yale University Press.

Saeed, Abdullah. (2003). Islam in Australia. NSW, Australia: Allen \& Unwin.

Sasson, Jean. Princess: A true story of life behind the veil in Saudi Arabia. London, U.K: Bantam Books.

van Nieuwkirk, K. (2003). Gender and conversion in the West. Austin: University of Texas Press. 